Politik Indonesia: Indonesian Political Science Review 2 (2) (2017) 100-120
Politik Indonesia
Indonesian Political Science Review
http://journal.unnes.ac.id/nju/index.php/JPI
Indonesia

\title{
Gejala Proliferasi Dinasti Politik di Banten Era Kepemimpinan Gubernur Ratu Atut Chosiyah
}

\author{
Agus Sutisna ${ }^{1 凶}$ \\ ${ }^{1}$ Universitas Muhammadiyah Tangerang, Indonesia
}

\begin{tabular}{|c|c|}
\hline Info Artikel & Abstrak \\
\hline $\begin{array}{l}\text { Sejarah Artikel: } \\
\text { Diterima } 27 \text { Maret } 2017 \\
\text { Disetujui } 17 \text { Mei } 2017 \\
\text { Dipublikasi } 15 \text { Juli } 2017\end{array}$ & $\begin{array}{l}\text { Sejak terbentuk menjadi provinsi yang mandiri, terpisah dari Jawa Barat, kehidupan } \\
\text { politik di Banten ditandai oleh menguatnya gejala dinasti politik atau politik } \\
\text { kekerabatan, baik pada tingkat provinsi maupun kabupaten/kota. Pada tingkat } \\
\text { provinsi, dominasi the local strongmen, Tb. Chasan Sochib dalam kepolitikan }\end{array}$ \\
\hline $\begin{array}{l}\text { Keywords: } \\
\text { Political Dynasties; } \\
\text { Governance Power; } \\
\text { Proliferation; Local } \\
\text { Strongmen; Banten Province }\end{array}$ & $\begin{array}{l}\text { Banten sangat menonjol dan berhasil menempatkan anaknya, Ratu Atut Chosiyah } \\
\text { pada jabatan gubernur selama hampir dua periode (2006-2011 dan 2011-2014). } \\
\text { Pasca keberhasilannya menduduki jabatan gubernur, secara hipotetik Ratu Atut } \\
\text { berhasil membangun dan mengembangkan dinasti politiknya ke berbagai arena } \\
\text { kehidupan masyarakat. Penelitian ini dilakukan pada obyek tatakelola dan praktik } \\
\text { kekuasaan pemerintahan gubernur di Provinsi Banten, dengan tujuan untuk } \\
\text { mengetahui dan menjelaskan bagaimana praktik dinasti politik atau politik } \\
\text { kekerabatan di Provinsi Banten pada era kepemimpinan Gubernur Ratu Atut } \\
\text { Chosiyah mengalami proliferasi (persebaran, pertumbuhan) di berbagai arena } \\
\text { kehidupan masyarakat. Penelitian ini menggunakan pendekatan kualitatif, dengan } \\
\text { metode pengumpulan data/informasi dilakukan melalui wawancara, triangulasi, } \\
\text { studi pustaka dan dokumen. Hasil penelitian menujukkan bahwa praktik dinasti } \\
\text { politik atau politik kekerabatan pada era kepemimpinan Gubernur Ratu Atut } \\
\text { Chosiyah di Banten memperlihatkan adanya gejala persebaran (proliferasi, } \\
\text { pertumbuhan), bukan saja pada ranah kekuasaan eksekutif dan legislatif, melainkan } \\
\text { juga menyebar di banyak arena kehidupan masyarakat, seperti pada arena kehidupan } \\
\text { bisnis, sosial-budaya, pendidikan, dan keormasan. }\end{array}$ \\
\hline
\end{tabular}

\begin{abstract}
$\overline{\text { Since forming into independent provinces, apart from West Java, Banten political }}$ life was marked by the strengthening of a political dynasty, both at the provincial and district and city. At the provincial level, the dominance of the local strongmen, Tb. Chasan Sochib in political of Banten is very prominent and managed to put his son, Ratu Atut Chosiyah the governorship for almost two periods (2006-2011 and 2011-2014). Post successes in occupying the post of governor, hypothetically Ratu Atut successfully builds and develop a political dynasty to the various arenas of public life. This research was carried out on the object of governance and practices of government power governor of Banten province, with the aim to identify and explain how political dynasties role this province or political kinship in Banten province in the era of the leadership of Governor Ratu Atut Chosiyah proliferate (distribution, diasporic) in various arenas of public life. This study used a qualitative approach, the method of collecting data and information through interviews, triangulation, literature and documents. The results showed that the role of political dynasties in the era of the l Governor Ratu Atut Chosiyah in Banten show any symptoms of the spread (proliferation, diasporic), not only in the realm of executive and legislative power, but also spread in many arenas of life of society, such as the arena business life, socio-cultural, educational, and organizational.
\end{abstract}

(c) 2017 Universitas Negeri Semarang

$\triangle$ Alamat korespondensi: ISSN $2477-8060$

Jalan Perintis Kemerdekaan I No. 33, Cikokol, Babakan, Kota Tangerang, Banten 15118, Indonesia

Email: tisna_1965@ymail.com 


\section{Pendahuluan}

Pasca berakhirnya rezim otoritarian orde baru tahun 1998 silam, semangat dan gairah berdemokrasi tumbuh di mana-mana. Situasi yang menurut Haryanto (2009) telah mengubah sistem politik dan melahirkan reformasi ini memberi peluang bagi berlangsungnya demokratisasi di Indonesia. Dalam konteks cakupan aktor penyelenggara kekuasaan, Tb. Massa Djafar (2008) melihat terjadi perubahan demikian rupa di mana aktor-aktor yang terlibat dalam proses kekuasaan semakin plural. Secara vertikal, perubahan kekuasaan menunjukkan bahwa politik tidak lagi didominasi pemerintah pusat. Demokrasi, meski tidak selalu mudah diwujudkan, memang diyakini oleh banyak pihak merupakan jalan yang paling tepat, sesuai natur kemanusiaan yang menghendaki kesetaraan, kebebasan dan partisipasi bersama, untuk mewujudkan masa depan tatakelola kehidupan bermasyarakat dan bernegara yang lebih baik. Itu sebabnya berbagai upaya penataan kelembagaan sistem politik sebagai wujud demokratisasi dilakukan di berbagai domain kehidupan politik, mulai dari pelaksanaan pemilu, penataan lembagalembaga politik kenegaraan, pengaturan baru relasi pemerintah pusat-daerah, penguatan kelompok-kelompok kepentingan dan lainlain (Marijan, 2011).

Namun demikian, jalan menuju demokrasi tidaklah selalu mudah diwujudkan. Fenomena semacam itu pula yang terjadi di Indonesia pasca runtuhnya rezim otoritarian
Orde Baru. Transisi dari rezim nondemokratik yang sentralistik menuju pemerintahan dan kehidupan politik yang sungguh-sungguh demokratis terbukti tidak mudah dilalui. Berbagai hambatan dan distorsi mewarnai lanskap kehidupan politik dan agenda konsolidasi demokrasi di Indonesia. Salah satu hambatan problematis yang sekaligus merupakan distorsi dalam kerangka demokratisasi dan penataan kehidupan politik yang lebih baik itu adalah munculnya fenomena dinasti politik di berbagai daerah.

Fenomena kehadiran dinasti politik -terutama di aras lokal-- dalam lanskap paradoks konsolidasi dan perkembangan demokrasi di Indonesia, merujuk pada data yang dirilis oleh Kementerian Dalam Negeri (Kemendagri) terbukti cukup massif (meluas), yakni bahwa pada akhir tahun 2013 silam terdapat 57 Kepala Daerah yang melakukan praktik politik dinasti. Data ini meningkat di awal tahun 2016 lalu menjadi lebih dari 65 daerah sebagaimana diungkapkan Siti Zuhro dalam seminar Korupsi dan Dinasti Politik di kantor PP Muhammadiyah Jakarta, 19 September 2016 (Zuhro, 2016). Kemudian, lebih dari data yang dirilis Kemendagri yang hanya menampilkan praktik dinasti politik di ranah eksekutif, dalam kenyataannya fenomena dinasti politik ini juga memperlihatkan gejala persebaran dan perluasan (proliferasi) ke arena kekuasaan dan jabatan-jabatan politik di lembaga egislatif, pusat maupun daerah. 
Setidaknya gejala ini terjadi di Provinsi Banten.

Dalam kasus Provinsi Banten, praktik dinasti politik memperlihatkan gejala proliferasi hingga ke luar arena kekuasaan eksekutif dan legislatif. Sejumlah anggota keluarga dan kerabat Gubernur Ratu Atut Chosiyah menduduki banyak asosiasi dan organisasi di luar pemerintahan. Mulai asosiasi bisnis terutama Kamar Dagang dan Industri (Kadin), partai politik (dalam hal ini Partai Golkar), organisasi keagamaan, organisasi pemuda, organisasi olahraga, organisasi pendekar, hingga organisasi sosialbudaya.

Studi tentang dinasti politik di Banten pernah dilakukan, setidaknya oleh tiga peneliti, yakni Leo Agustino bertajuk "Dinasti Politik Pasca-Otonomi Orde Baru: Pengalaman Banten” (Majalah Prisma, 2010) dan Politik Lokal dan Otonomi Daerah (2014); Yoes C. Kenawas, bertajuk "The Rise of Political Dynasties in a Democratic Society" (Paper pada Simposium Arryman Fellow, 2014); dan Abdul Hamid bertajuk Observation of Democratic Decentralization in Indonesia during 2009-2014: Political Dynasty in Banten Province and Populism in Jakarta Province (Disertasi, 2016).

Dalam studinya di dua artikel itu, Leo terutama mengkaji dua hal penting dari fenomena munculnya dinasti politik di Banten, yakni muasal kemunculan dinasti dan dampak ekonomi-politik yang ditimbulkannya. Dengan menggunakan pendekatan elit yang memposisikan isu dinasti politik dalam kerangka kajian mengenai peranan elit politik dalam struktur masyarakat, Leo menyimpulkan bahwa kemunculan dinasti politik di Banten tidak terlepas dari peran dan ketokohan Chasan Sochib (ayahanda Ratu Atut) sebagai elit lokal yang dengan ambisinya berhasil mengendalikan kehidupan ekonomi-politik pasca Banten menjadi provinsi tahun 2000. Ambisi Sochib untuk menguasai panggung kepolitikan Banten ini menemukan "jalan mudahnya" dengan terbukanya kesempatan yang disediakan atau tercipta oleh sebab terjadinya proses perubahan politik dari era otoritarian ke era demokrasi. Tetapi Leo tidak menganalisis bagaimana strategi politik Ratu Atut dalam memelihara dan mengembangkan dinasti politiknya di kemudian hari, paling tidak setelah Ratu Atut menduduki jabatan Gubernur definitif hasil Pilgub tahun 2006.

Dengan fokus studi yang tidak jauh berbeda, yakni mengeksplorasi gejala kebangkitan dinasti politik di Banten, dalam papernya yang dipresentasikan pada Simposium Arryman Fellow pada tahun 2014 Yoes menyimpulkan, bahwa secara umum faktor-faktor penentu keberhasilan dalam membangun dinasti politik adalah adanya topangan kekuatan jaringan keluarga informal dan akumulasi kekayaan materi (finansial). Dalam kasus Banten, Yoes menyimpulkan bahwa kemunculan dinasti politik tidak terlepas dari sosok Chasan Sochib sebagai salah satu tokoh pembentukan Provinsi 
Banten yang paling berpengaruh. Chasan Sochib membangun pondasi awal dinasti politik di Banten dengan topangan tiga sumberdaya, yakni (1) sumberdaya finansial yang diperolehnya dari akses eksklusif terhadap proyek-proyek pemerintah, (2) sarana koersif (kekerasan) yang dilakukan oleh para jawara yang diikatnya melalui tradisi patronase, dan (3) kontrol terhadap partai politik, dalam hal ini Partai Golkar yang sejak era orde baru telah didominasinya bersama anggota keluarga dan kerabatnya.

Kemudian untuk mengkonsolidasikan dan memperluas jaringan dinasti politiknya, Yoes menyimpulkan bahwa dinasti Rau, terutama sejak Pilgub Banten 2001 --dimana Ratu Atut berhasil menduduki kursi Wakil Gubernur mendampingi Djoko Munandar-yang "dimenangkannya", berupaya keras menciptakan arena partisipasi kepolitikan lokal menjadi sempit dan terbatas bagi pihakpihak lain, di samping dengan cara menghalangi intervensi dari otoritas kekuasaan pusat. Yoes, seperti juga Leo, tidak membahas lebih jauh bagaimana dinasti politik yang dibangun Sochib mengalami proliferasi di era kepemimpinan Gubernur Ratu Atut.

Agak berbeda dengan Leo dan Yoes, disertasi Hamid membahas fenomena dinasti politik di Provinsi Banten dalam konteks isu yang mendahuluinya, yakni desentralisasi di Indonesia pasca kejatuhan rezim Soeharto yang telah mengubah sistim politik dari sentralistik yang otoriter ke desentralistik yang demokratis. Artinya, kajian Hamid tidak membahas secara khusus fenomena dinasti politik di Banten, melainkan hanya memposisikannya sebagai salah satu implikasi politik dari penerapan desentralisasi dalam kerangka otonomi daerah. Implikasi ini dibahas dalam suatu studi banding dengan fenomena yang secara diametral berhadaphadapan namun keduanya sama-sama merupakan buah implikasi dari penerapan desentralisasi, yakni fenomena populisme.

Dalam kajiannya Hamid menjelaskan, bahwa era desentralisasi yang untuk pertama kalinya dilandasi penerapannya oleh UU Nomor 22 Tahun 1999 tentang Pemerintahan Daerah telah melahirkan dua tipologi kepemimpinan dan tatakelola kekuasaan lokal yang secara diametral sangat paradoks, yakni dinasti dan populisme. Gejala dinasti tumbuh di sejumlah daerah, salah satunya yang relatif kuat adalah di Provinsi Banten pada masa kepemimpinan Gubernur Ratu Atut Chosiyah. Sementara itu gejala populisme tumbuh antara lain di Provinsi DKI Jakarta yang mengemuka pada saat perhelatan Pilgub DKI Jakarta tahun 2012 dan kurang lebih selama dua tahun kepemimpinan Jokowi di Jakarta.

Menurut Hamid, sejarah kemunculan dan pembentukan dinasti politik di Banten bermuara pada sosok dan perilaku politik $\mathrm{Tb}$. Chasan Sochib (ayahanda Ratu Atut) yang memanfaatkan momentum pelaksanaan otonomi daerah dan Pilgub pertama, dengan mengandalkan kekerasan untuk mencapai dan mempertahankan kekuasaan politiknya. 
Setelah kekuasaan politik berada dalam kontrolnya, Sochib kemudian memanfaatkan keluarga dan jaringan kerabatnya untuk memperluas dan mengembangkan dominasinya hingga akhirnya berhasil mengontrol arena kepolitikan lokal di Banten. Tetapi seperti dua peneliti terdahulu, Hamid juga tidak membahas lebih jauh bagaimana dinasti politik yang dibangun Sochib mengalami proliferasi di era kepemimpinan anaknya hingga ke arena kehidupan di luar ranah eksekutif dan legislatif.

Membandingkan dengan studi-studi terdahulu sebagaimana diuraikan di atas, kebaruan ilmiah pada kajian di dalam artikel ini adalah berkenaan dengan gejala proliferasi dinasti politik yang dirintis dan dibangun oleh Chasan Sochib pada era kepemimpinan Gubernur Ratu Atut Chosiyah di banyak arena kehidupan di luar ranah eksekutif dan legislatif di Provinsi Banten.

Berlatar uraian tersebut di atas, fokus permasalahan dalam studi ini adalah bagaimana dinasti politik yang dibangun Chasan Sochib itu mengalami proliferasi (perluasan dan pertumbuhan) di banyak arena kehidupan masyarakat pada era kepemimpinan Gubernur Ratu Atut Chosiyah (2005-2013)?

Dengan demikian maka tujuan penelitian ini adalah untuk mendalami dan mengeksplorasi bagaimana dinasti politik di Banten pada masa kepemimpinan Gubernur Ratu Atut mengalami proliferasi sedemikian rupa hingga merambah ke banyak arena kehidupan masyarakat Banten.

\section{Kajian Pustaka}

Metodologi

Obyek dan Lokasi Penelitian. Obyek penelitian adalah tatakelola pemerintahan Provinsi Banten pada era kepemimpinan Gubenur Ratu Atut tahun 2005 hingga tahun 2013. Penelitian dibatasi hanya pada isu gejala proliferasi (persebaran, perluasan dan pertumbuhan) dinasti politik di banyak arena kehidupan masyarakat Banten, yang secara hipotetik terjadi pada era kemimpinan Gubernur Ratu Atut.

Penelitian ini menggunakan pendekatan Kualitatif. Metode ini dipilih mengingat ruanglingkup permasalahan yang cukup luas dan memiliki keterkaitan fenomenologis yang multidimensi di antara isu-isu, data/informasi, fakta dan peristiwaperistiwa empiriknya. Dengan metode ini diharapkan pokok dan ruanglingkup permasalahan penelitian dapat dieksplorasi dan difahami secara utuh, komprehensif dan mendalam.

Data dalam penelitian ini dieksplorasi dan dihimpun (data collection) dengan berbagai teknik yang lazim digunakan dalam penelitian kualitatif, tetapi disesuaikan penggunaannya dengan jenis dan ruanglingkup data yang dibutuhkan. Untuk berbagai data sekunder seperti literaturliteratur kajian sejenis dan rujukan-rujukan yang bernilai akademik (buku, jurnal dan 
laporan-laporan karya ilmiah seperti tesis dan disertasi), dokumen-dokumen berbagai peraturan perundangan yang relevan, serta sumber-sumber tertulis lainnya seperti berita dan artikel opini di media masa, dan lain-lain akan dikumpulkan dengan menggunakan teknik studi dokumen.

Sedangkan untuk berbagai data primer akan digunakan teknik wawancara semi-terstruktur (semistructure interview); dan dilakukan dengan tatap muka langsung dengan narasumber penelitian. Wawancara dalam penelitian akan dilakukan dengan teknik topic guides, dimana wawancara akan lebih fokus pada topik, bukan pada pertanyaan. Di samping kedua teknik pengumpulan data tersebut, untuk memperoleh gambaran, terutama "suasana psiko-politiknya" yang utuh mengenai lokasi (place) penelitian sehingga peneliti dapat menangkap dan memahami "situasi sosiopolitik" yang mungkin dibutuhkan dalam tahapan analisis data dan penyajian hasil penelitian, peneliti juga akan melakukan pengamatan langsung (observation) terhadap lokasi penelitian, khususnya pada tempattempat atau lokasi di Banten yang memiliki hubungan tematik dengan data/informasi yang dibutuhkan. Terakhir, untuk berbagai data atau informasi (termasuk pikiran, pandangan dan sikap) narasumber dan atau data dan informasi yang berasal dari sumber-sumber sekunder yang bersifat meluas (convergen), tidak konsisten bahkan kontradiktif, peneliti akan menggunakan teknik triangulasi (triangulation) seperlunya.

Narasumber atau informan serta besaran jumlahnya dalam penelitian ini dipilih berdasarkan karakteristik yang lazim digunakan dalam pendekatan kualitatif. Mengikuti sebagian saran Spradley (Sugiyono, 2008), narasumber dalam penelitian ini adalah orang-orang yang memiliki keterlibatan mendalam dan luas dengan isu dinamika kepolitikan lokal (Banten); memahami konteks dan substansi pokok permasalahan yang diteliti; serta dapat diperkirakan mampu bersikap obyektif dalam memberikan pandangan dan penyikapan terhadap setiap aspek dari isu penelitian yang ditanyakan.

Adapun teknik analisis data dalam penelitian ini akan menggunakan model yang ditawarkan Miles dan Huberman (Sugiyono, 2008), suatu teknik dimana data dianalisis secara interaktif dan berlangsung secara terus menerus sampai tuntas, atau peneliti menganggap data dan informasi yang diperlukan memadai (data jenuh). Model ini terdiri dari tiga rangkaian terpadu, yaitu: penyederhanaan data (data reduction), penyajian data (display data), dan penarikan kesimpulan atau verifikasi (conclusion drawing/verification).

\section{Kajian Konseptual}

Studi mengenai dinasti politik telah banyak dilakukan para ilmuwan politik di berbagai negara. Beberapa peneliti yang 
tulisannya banyak dirujuk antara lain Pablo Querubin, Mark R. Thompson, Ernesto Dal Bo, Jason Snyder, Alfred W. McCoy, Donn M. Kurtz, Yasushi Asako, dan Stephen Hess.

Pada umumnya posisi kajian mengenai isu dinasti politik ini berada dalam konteks perbincangan mengenai politik kekerabatan (keluarga) sebagaimana dapat dibaca dalam cara bagaimana para ahli itu mendefinisikan dinasti politik. Pablo Querubin (2010) mendefinisikan dinasti politik sebagai sejumlah kecil keluarga yang mendominasi distribusi kekuasaan dalam area geografis tertentu. Mark R. Thompson (2012) menjelaskan dinasti politik hanya sebagai jenis lain dari transisi (peralihan) kekuasaan politik, langsung maupun tidak langsung, yang melibatkan anggota keluarga. Definisi ini tidak jauh berbeda dengan yang dirumuskan Yasushi Asako dkk (2012) yang mendefinisikan dinasti politik secara sederhana sebagai sekelompok politisi yang mewarisi jabatan publik dari salah satu anggota keluarga mereka.

Kebangkitan dinasti politik, sebagaimana ditunjukkan oleh banyak hasil studi yang dilakukan para ahli di berbagai negara memang memiliki hubungan sangat erat dengan kepentingan keluarga atau politik kekerabatan. Kepentingan keluarga kerap, jika tidak selalu, menjadi basis muasal pertumbuhan, perkembangan dan perluasan dinasti politik dalam suatu sistim politik demokrasi. Dalam tradisi politik kekerabatan, anggota keluarga yang sudah menjadi penguasa atau menduduki jabatan publik pada umumnya akan melakukan praktik nepotisme dengan memberikan berbagai perlakuan istimewa kepada anggota keluarga atau kerabatnya, bukan untuk mensejahterakan rakyat dan memajukan daerahnya, melainkan dalam rangka membangun dan memperkuat jejaring kekuasannya. Dari sinilah kemudian embrio dinasti politik itu muncul.

Dalam studi Eisenstadt S.N. dan Roniger Luis (1984) dikemukakan, bahwa pemberian prioritas kepada anggota keluarga dan kerabat dalam kehidupan politik itu didasarkan pada 4 (empat) argumentasi, yakni: (1) Kepercayaan (trusty), maksudnya bahwa keluarga atau kerabat lebih dapat dipercaya dan tak mungkin berkhianat seperti yang lazim dilakukan politisi pemburu kekuasaan; (2) Kesetiaan (loyality), bahwa kerabat akan jauh memiliki loyalitas tinggi dalam konteks menjalankan semua tugas politik terutama dalam hal menjaga wibawa dan kehormatan kerabat besar ketimbang orang lain; (3) Solidaritas (solidarity), artinya kerabat dipastikan jauh memiliki tingkat solidaritas yang tangguh terutama dalam menolong klan keluarga besar dari kebangkrutan kekuasaan dan kekayaan ketimbang mereka yang bukan dari kalangan kerabat; (4) Proteksi (protection), hal ini terkait dengan kepentingan mempertahankan gengsi dan kehormatan keluarga besar. Mereka yang berasal dari klan yang sama akan cenderung mampu menjaga apa yang telah dimiliki keluarga ketimbang orang lain. 
Secara teoritik praktik dinasti politik menimbulkan berbagai ancaman problematis dalam kehidupan politik di aras lokal. Dalam kerangka konsolidasi demokrasi lokal, praktik dinasti politik mempersempit ruang partisipasi publik sekaligus menegasikan salah satu prinsip dasar demokrasi, yakni kesetaraan politik. Selain itu, dinasti politik juga hanya akan memperkokoh gejala oligarkis di daerah yang berpotensi melemahkan mekanisme check and balance karena jabatan-jabatan politik dikuasai oleh satu keluarga. Dalam pandangan Amich Alhumami (2016), peneliti sosial di University of Sussex Inggris politik kekerabatan atau dinasti politik tidak sesuai dengan prinsip meritokrasi. Sebab, proses rekrutmen didasarkan pada sentimen kekeluargaan, bukan kompetensi. Menurutnya, jika terus berlanjut, gejala ini bisa kontraproduktif bagi ikhtiar membangun sistem demokrasi modern. Dominasi kekuasaan oleh sekelompok elit lokal atau keluarga yang demikian itu pada akhirnya akan menimbulkan kerawanan terjadinya berbagai bentuk penyalahgunaan (korupsi) kekuasaan politik maupun ekonomi.

Senada dengan pandangan di atas, merujuk pada kajian John T. Sidel (1999) tentang local bossism misalnya, dapat disimpulkan bahwa kehadiran model-model oligarkis, personalisme dan klientilisme -yang kesemuanya menjadi ruh (esensi) dari karakteristik dinasti politik-- telah menghambat proses konsolidasi dan pembangunan demokrasi di tingkat lokal.
Dalam bukunya yang lain, Sidel bahkan menuding praktik dinasti sebagai pihak paling bertanggung jawab atas maraknya gejala personalisasi politik dan lemahnya kapasitas negara dan institusi politik. Proses pengambilan keputusan tak lagi didasarkan pada proses rasionalitas instrumental, tetapi didasarkan pada keputusan individual dari aktor-aktor dinasti yang berkuasa. Pelembagaan partai politik juga tersumbat karena asas meritokrasi ditundukkan oleh hubungan darah dan hubungan keluarga.

Kemudian dalam konteks ekonomi lokal, praktik dinasti politik juga dapat melahirkan kapitalisme klientilistik sebagai bagian dari kronisme, di mana pelaku investasi ekonomi tidak serta merta bebas melakukan aktivitasnya karena senantiasa dimintai upeti oleh kerabat kepala daerah. Sementara Leo Agustino (2014) melihat, bahwa praktik dinasti politik memberi pengaruh buruk pada pembangunan sosialpolitik dan sosial-ekonomi, karena peluang politik dan ekonomi setiap warga negara menjadi amat terbatas sebab dimonopoli oleh penguasa serta keluarga dan para kerabatnya.

\section{Temuan dan Diskusi}

\section{Proliferasi di Arena Eksekutif dan Legislatif}

Sebagaimana telah disinggung di depan, starting point kemunculan fenomena dinasti politik di Banten dimulai sejak Ratu Atut Chosiyah naik posisi dari Wakil Gubernur menjadi Pelaksana Tugas (Plt) Gubernur pada tahun 2005, menggantikan 
Djoko Munandar, Gubernur Banten definitif pertama pasca provinsi yang diberhentikan karena kasus korupsi dana perumahan anggota DPRD Banten. Namun demikian, sinyal dan potensi ke arah terbentuknya dinasti politik sebetulnya sudah mulai tampak sejak Pilgub pertama tahun 2001. Sinyal dan potensi itu paling tidak, tampak pada dominasi $\mathrm{Tb}$. Chasan Sochib, ayahanda Ratu Atut, dengan kekuatan jaringan jawaranya yang mendominasi jalannya proses perhelatan Pilgub pada waktu itu.

Kurang lebih setahun setelah menjabat sebagai Plt Gubernur Banten, tahun 2006 Pilgub Banten kedua yang untuk pertama kalinya dilaksanakan secara langsung digelar. Ratu Atut kemudian maju sebagai calon Gubernur didampingi Masduki, dan terpilih. Sejak menjadi orang nomor satu di Banten inilah, satu per satu anggota keluarga besar Ratu Atut masuk ke arena politik praktis, baik di lembaga eksekutif maupun legislatif di berbagai tingkatan lembaga perwakilan.

Diawali oleh Airin Rachmi Diany yang maju dalam Pilkada Kabupaten Tangerang tahun 2008 sebagai calon Wakil Bupati mendampingi Jazuli Juwaini (politisi PKS). Airin adalah adik ipar Ratu Atut; isteri Tb. Chaeri Wardana. Pada waktu itu pasangan mereka dikalahkan pasangan petahana, Ismet Iskandar-Rano Karno. Pada tahun ini juga adik tiri Atut, Tubagus Haerul Jaman, maju sebagai calon Wakil Walikota Serang berpasangan dengan Bunyamin dan menang.
Tidak sampai tiga tahun kemudian, Jaman naik menjadi Walikota Serang, menggantikan Bunyamin yang meninggal dunia. Pada Pilkada Kota Serang tahun 2013, Jaman kembali maju dan menang.

Tahun 2010, giliran adik kandung Ratu Atut, Ratu Tatu Chasanah, mengikuti Pilkada Kabupaten Serang sebagai calon Wakil Bupati Serang 2010-2015 mendampingi Taufik Nuriman dan terpilih. Pada tahun 2010 ini juga, Airin yang gagal di Pilkada Kabupaten Tangerang tahun 2008, kembali maju pada Pilkada Kota Tangerang Selatan sebagai calon Walikota. Berpasangan dengan Benyamin Davnie, Airin akhirnya terpilih sebagai Wali Kota Tangerang Selatan 2011-2015.

Tahun 2011, Heryani, ibu tiri Ratu Atut, juga tak ketinggalan. Ia maju sebagai calon Wakil Bupati Kabuapaten Pandeglang periode 2011-2016 mendampingi Erwan Kurtubi dan terpilih. Pada tahun ini pula Ratu Atut kembali mencalonkan diri sebagai Gubernur Banten didampingi Rano Karno. Untuk kedua kalinya, Ratu Atut terpilih sebagai Gubernur Banten periode 2012-2017, hingga akhirnya datanglah malapetaka itu: Ratu Atut divonis 4 tahun (kemudian diperberat menjadi 7 tahun oleh MA) karena terbukti melakukan penyuapan terhadap Akil Mochtar untuk memenangi gugatan PHPU Pemilukada Lebak tahun 2013 bersama Wawan yang divonis 5 tahun penjara oleh Majelis Hakim Tipikor. 
Selain pada ranah eksekutif dan legislatif (politik), dinasti politik Ratu Atut telah menancapkan pondasi hegemoninya dalam banyak cakupan arena kehidupan masyarakat, termasuk dalam pada ranah kehidupan ekonomi, sosial-budaya, bahkan keagamaan. Dalam perspektif pemetaan tipologi dinasti, fenomena kehadiran dinasti politik yang dirintis Chasan Sochib serta dibangun dan dikembangkan kemudian oleh Ratu Atut Chosiyah sejak tahun 2005 ini dapat dikategorikan sebagai tipe octopussy dynasties. Suatu istilah yang merujuk pada betapa luasnya dimensi cakupan dari dominasi kekuasaan dinasti politik yang dikembangkannya.

Di arena politik, selain berhasil menempatkan keluarganya di panggung kekuasaan eksekutif sebagaimana dipetakan di depan, dinasti politik Ratu Atut juga sukses mengantarkan anggota keluarga lainnya di panggung legislatif. Pada Pemilu 2009, suami Ratu Atut, almarhum Hikmat Tomet, terpilih menjadi anggota DPR RI dari Partai Golkar. Pada Pemilu yang sama, anak pertama mereka yang masih berstatus mahasiswa ketika itu, Andika Hazrumy, terpilih menjadi anggota DPD, mewakili Provinsi Banten; dan istrinya, Ade Rossi Khairunnisa terpilih menjadi anggota DPRD Kota Serang.

Tabel 1. Proliferasi Dinasti di Arena Eksekutif dan Legislatif Era Kepemimpinan Gubernur Banten Ratu Atut 2006-2013.

\begin{tabular}{|c|c|c|c|c|}
\hline No & Nama & $\begin{array}{c}\text { Jabatan } \\
\text { Eksekutif }\end{array}$ & $\begin{array}{c}\text { Jabatan } \\
\text { Legislatif }\end{array}$ & $\begin{array}{c}\text { Hubungan } \\
\text { Keluarga }\end{array}$ \\
\hline 1 & $\begin{array}{c}\text { Tb. Khaerul } \\
\text { Jaman }\end{array}$ & $\begin{array}{c}\text { Wakil } \\
\text { Walikota, }\end{array}$ & - & Adik \\
\hline
\end{tabular}

\begin{tabular}{|c|c|c|c|c|}
\hline & & $\begin{array}{l}\text { Walikota } \\
\text { Serang }\end{array}$ & & \\
\hline 2 & $\begin{array}{c}\text { Airin Rachmi } \\
\text { Diani }\end{array}$ & $\begin{array}{l}\text { Walikota } \\
\text { Tangsel }\end{array}$ & - & Adik ipar \\
\hline 3 & Tatu Chasanah & $\begin{array}{l}\text { Wabup } \\
\text { Serang }\end{array}$ & - & Adik \\
\hline 4 & Heryani & $\begin{array}{c}\text { Wabup } \\
\text { Pandeglang }\end{array}$ & - & Ibu tiri \\
\hline 5 & Hikmat Tomet & - & $\begin{array}{l}\text { Anggota } \\
\text { DPR RI }\end{array}$ & $\begin{array}{l}\text { Suami } \\
\text { (alm) }\end{array}$ \\
\hline 6 & $\begin{array}{c}\text { Andika } \\
\text { Hazrumy }\end{array}$ & - & $\begin{array}{l}\text { Anggota } \\
\text { DPD RI, } \\
\text { Anggota } \\
\text { DPR RI }\end{array}$ & Anak \\
\hline 7 & Ade Rossi Ch & - & $\begin{array}{c}\text { Anggota } \\
\text { DPRD } \\
\text { Kota } \\
\text { Serang, } \\
\text { Anggota } \\
\text { DPRD } \\
\text { Banten } \\
\end{array}$ & Menantu \\
\hline 8 & $\begin{array}{c}\text { Ratna } \\
\text { Komalasari }\end{array}$ & - & $\begin{array}{c}\text { Anggota } \\
\text { DPRD } \\
\text { Kota } \\
\text { Serang }\end{array}$ & Ibu tiri \\
\hline 9 & $\begin{array}{c}\text { Aden A. } \\
\text { Kholik }\end{array}$ & - & $\begin{array}{l}\text { Anggota } \\
\text { DPRD } \\
\text { Provinsi } \\
\text { Banten }\end{array}$ & Adik ipar \\
\hline
\end{tabular}

Sumber: Data diolah dari berbagai sumber.

Hasil Pemilu 2014 semakin memantapkan posisi dinasti Ratu Atut di lembaga legislatif, dengan keberhasilannya mengirimkan dua putra/putrinya ke Senayan: Andika Hazrumy terpilih menjadi anggota DPR RI dari Partai Golkar, dan Andiara Apriala Hikmat terpilih menjadi anggota DPD RI mewakili Provinsi Banten. Sementara itu, dua menantu, masing-masing Ade Rossi Khoerunnisa (istri Andika Hazrumy) dan Tanto Warsono Arban (suami Andiara Aprilia Hikmat) juga terpilih menjadi anggota DPRD Banten.

\section{Proliferasi di Arena Non Negara}

Selain di eksekutif dan lembaga legislatif, Ratu Atut Chosiyah juga berhasil memperluas jejaring dinastinya di Banten dengan menempatkan sejumlah anggota keluarganya di berbagai Ormas, selain tentu 
saja mendominasi kepengurusan Partai Golkar di Provinsi Banten, partai yang menjadi tunggangan utama Ratu Atut di pentas kepolitikan Banten.

Sesuai karakteristiknya sebagai model octopussy dynasties (Djati, 2013), temuan studi ini menunjukkan dinasti politik Ratu Atut meluas dan merambah ke banyak ranah kehidupan di Banten. Mulai dari asosiasi bisnis terutama Kamar Dagang dan Industri (Kadin), partai politik (dalam hal ini Partai Golkar), organisasi keagamaan, organisasi pemuda, organisasi olahraga, organisasi pendekar, hingga organisasi sosial-budaya.

Kadin misalnya, sejak dibentuk pada bulan Desember tahun 2000, langsung dipimpin oleh $\mathrm{Tb}$. Chasan Sochib hingga tahun 2012, kemudian dilanjutkan oleh Tb. Chaeri Wardana, adik Ratu Atut hingga (mestinya) sampai tahun 2017. Selain di pucuk pimpinan, keluarga Ratu Atut juga banyak yang masuk kedalam struktur kepengurusan Kadin Provinsi Banten. Chasan Sochib sendiri, selain memimpin Kadin dan organisasi kependekaran seperti Persatuan Pendekar Persilatan dan Seni Budaya Banten (PPPSBB) juga memimpin DPP Satuan Karya Ulama (dua periode) hingga ajal menghentikan kiprahnya pada tanggal 30 Juni 2011 silam.

Tabel 2. Dominasi Keluarga Dinasti di Kadin Provinsi Banten Era Kepemimpinan Gubernur Banten Ratu Atut 2006-2013.

\begin{tabular}{|c|l|l|c|}
\hline No & \multicolumn{1}{|c|}{ Nama } & Jabatan & $\begin{array}{c}\text { Hubungan } \\
\text { Keluarga }\end{array}$ \\
\hline 1 & Tb. Chaeri Wardana & Ketua Umum & Adik \\
\hline 2 & Hikmat Tomet & Ketua Dewan & Suami (alm) \\
\hline
\end{tabular}

\begin{tabular}{|c|c|c|c|}
\hline & & Penasihat & \\
\hline 3 & Ratu Tatu Chasanag & $\begin{array}{c}\text { Anggota Dewan } \\
\text { Penasihat }\end{array}$ & Adik \\
\hline 4 & Tb. Khaerul Jaman & $\begin{array}{c}\text { Anggota Dewan } \\
\text { Penasihat }\end{array}$ & Adik \\
\hline 5 & Aden Abdul Khalik & $\begin{array}{c}\text { Anggota Dewan } \\
\text { Penasihat }\end{array}$ & Adik ipar \\
\hline 6 & Ratu Lilis Karyawati & $\begin{array}{l}\text { Wakil Ketua } \\
\text { Umum } \\
\text { Bidang } \\
\text { Perikanan dan } \\
\text { Kelautan } \\
\end{array}$ & Adik tiri \\
\hline 7 & Ratu Ella Syatibi & $\begin{array}{l}\text { Wakil Ketua } \\
\text { Umum } \\
\text { Bidang } \\
\text { Perkebunan dan } \\
\text { Kehutanan }\end{array}$ & Sepupu \\
\hline 8 & Ratu Wawat Cherawati & $\begin{array}{l}\text { Ketua Komite } \\
\text { Tetap } \\
\text { Pengolahan dan } \\
\text { Pemanfaatan } \\
\text { Limbah Industri } \\
\text { Pertambangan }\end{array}$ & Adik tiri \\
\hline 9 & $\begin{array}{l}\text { Ratu Heni } \\
\text { Chendrayani }\end{array}$ & $\begin{array}{c}\text { Ketua Komite } \\
\text { Tetap } \\
\text { Asurasi } \\
\text { Kendaranaan }\end{array}$ & Adik tiri \\
\hline
\end{tabular}

Sumber: Gatra, No.52 Tahun XIX, 31 Oktober-6 November 2013.

Di Partai Golkar, hingga saat ini keluarga Ratu Atut masih mendominasi kepemimpinan di Banten. Tatu Chasanah, adik kandungnya terpilih menjadi Ketua DPD I Partai Golkar Provinsi Banten, menggantikan Ketua sebelumnya, Hikmat Tomet yang tidak lain adalah suami Ratu Atut pada tahun 2014. Sementara itu, Haerul Jaman, adik tiri Ratu Atut, sejak Januari 2015 terpilih menjadi Plt Ketua DPD II Partai Golkar Kota Serang, menggantikan Ketua sebelumnya Ratu Lilis Karyawati yang juga adik tiri Ratu Atut.

Tabel 3. Dominasi dan Jejaring Keluarga Dinasti di Partai Golkar Era Kepemimpinan Gubernur Banten Ratu Atut 2006-2013.

\begin{tabular}{|c|c|c|}
\hline No & Nama & Jabatan \\
\hline 1 & Ratu Atut Chosiyah & $\begin{array}{c}\text { Wakil Bendahara Umum } \\
\text { DPP Partai Golkar }\end{array}$ \\
\hline 2 & Hikmat Tomet & $\begin{array}{c}\text { Ketua DPD Partai Golkar } \\
\text { Banten }\end{array}$ \\
\hline 3 & Ratu Tatu Chasanah & Ketua DPD Partai Golkar \\
\hline
\end{tabular}




\begin{tabular}{|c|c|c|}
\hline & & Kabupaten Pandeglang \\
\hline 4 & Ratu Lilis Karyawati & $\begin{array}{c}\text { Ketua DPD Partai Golkar } \\
\text { Kota Serang }\end{array}$ \\
\hline 5 & Tb. Chaeri Wardana & $\begin{array}{c}\text { Ketua Angkatan Muda Partai } \\
\text { Golkar Provinsi Banten }\end{array}$ \\
\hline
\end{tabular}

Sumber: Data diolah dari berbagai sumber.

Dominasi keluarga Ratu Atut di luar ranah eksekutif, legislatif dan partai politik, berdasarkan data hingga tahun 2011 antara lain sebagai berikut: Aden Abdul Kholiq, (suami Ratu Lilis Karyawati, adik tiri Ratu Atut) menjadi Ketua DPD KNPI Provinsi Banten hingga tahun 2013, kemudian digantikan oleh Tanto W. Arban (menantu); Andika Hazrumy (anak Ratu Atut) menjadi Ketua Tagana Banten, Wakil Ketua GP. Anshor Banten, dan Bendahara Karang Taruna Banten; Ade Rossi Khaerunnisa (menantu Ratu Atut) menjadi Ketua KONI Serang dan Ketua Himpaudi Banten; Tatu Chasanah (adik Ratu Atut) menjadi Ketua PMI Banten; Ratna Komalasari (mertua tiri) menjadi Ketua Parfi Banten.

\begin{tabular}{|c|c|c|c|}
\hline No & Nama & $\begin{array}{l}\text { Organisasi/Asosiasi } \\
\text { dan Posisi Jabatan }\end{array}$ & $\begin{array}{c}\text { Hubungan } \\
\text { Keluarga }\end{array}$ \\
\hline 1 & $\begin{array}{l}\text { Tb. Chaeri } \\
\text { Wardana }\end{array}$ & $\begin{array}{l}\text { Kadin Banten } \\
\text { (Ketua), } \\
\text { Pengprov } \\
\text { Taekwondo Banten } \\
\text { (Ketua) }\end{array}$ & Adik \\
\hline 2 & $\begin{array}{l}\text { Tb. Khaerul } \\
\text { Jaman }\end{array}$ & IMI Banten (Ketua) & Adik \\
\hline 3 & $\begin{array}{l}\text { Ratu Tatu } \\
\text { Chasanah }\end{array}$ & $\begin{array}{l}\text { PMI Banten } \\
\text { (Ketua), Masyarakat } \\
\text { Agribisnis dan } \\
\text { Agroiindustri } \\
\text { Indonesia Banten } \\
\text { (Ketua), GWKS } \\
\text { (Ketua), Dekopinda } \\
\text { (Ketua), Forum } \\
\text { Paguyuban Banten } \\
\text { Bersatu (Ketua), } \\
\text { Koalisi Politisi } \\
\text { Perempuan } \\
\text { Indonesia Banten } \\
\text { (Ketua) }\end{array}$ & Adik \\
\hline 4 & $\begin{array}{l}\text { Andika } \\
\text { Hazrumy }\end{array}$ & $\begin{array}{l}\text { Karang Taruna } \\
\text { Banten (Ketua), } \\
\text { Tagana Banten } \\
\text { (Ketua), dan } \\
\text { PW GP Anshor } \\
\text { Banten (Bendahara) } \\
\end{array}$ & Anak \\
\hline 5 & Ade Rossi Ch & Himpaudi Banten & Menantu \\
\hline
\end{tabular}

\begin{tabular}{|c|c|c|c|}
\hline & & $\begin{array}{l}\text { (Ketua), P2TP2A } \\
\text { Banten (Ketua), } \\
\text { KONI Kota Serang } \\
\text { (Ketua), } \\
\text { dan PMI Kota } \\
\text { Serang (Ketua) }\end{array}$ & \\
\hline 6 & Hikmat Tomet & Dekranasda (Ketua) & $\begin{array}{c}\text { Suami } \\
\text { (alm) }\end{array}$ \\
\hline 7 & $\begin{array}{l}\text { Aden A. } \\
\text { Kholik }\end{array}$ & $\begin{array}{l}\text { DPD KNPI Banten } \\
\text { (Ketua), } \\
\text { Perbasi Kota Serang } \\
\text { (Ketua) }\end{array}$ & Adik ipar \\
\hline 8 & $\begin{array}{l}\text { Ratna } \\
\text { Komalasari }\end{array}$ & $\begin{array}{l}\text { PARFI Banten } \\
\text { (Ketua) }\end{array}$ & Ibu tiri \\
\hline 9 & $\begin{array}{l}\text { Tanto W. } \\
\text { Arban }\end{array}$ & $\begin{array}{l}\text { HIPMI Banten } \\
\text { (Ketua), } \\
\text { GP Anshor Kota } \\
\text { Tangsel (Ketua), }\end{array}$ & Menantu \\
\hline
\end{tabular}

Sumber: Data diolah dari berbagai sumber.

Mengikuti tipologi Wasisto Raharjo

Djati (2013), proliferasi dinasti Ratu Atut sebagaimana diuraikan di atas dan ditunjukkan dalam tabel 3 , dengan jelas menunjukkan model dinasti gurita (octopussy dynasties). Layaknya sebuah gurita, tentakeltentakelnya menjalar ke berbagai arah untuk menempatkan keluarga atau kroninya dalam berbagai posisi jabatan publik di Banten, baik di arena politik (eksekutif dan legislatif) maupun non-politik (bisnis, sosial, kepemudaan bahkan keagamaan).

\section{Strategi Politik dan Modal Materi Dinasti}

Keberhasilan Ratu Atut mengembangkan dinasti politiknya di berbagai ranah kehidupan politik di Banten secara hipotetis tidak terlepas dari dukungan politik massa, jejaring yang dimiliki dan dapat dikooptasi, serta modal materi (sumber daya finansial) yang dimiliki Ratu Atut dan keluarga besarnya. Dukungan publik itu berasal dan direpresentasikan oleh berbagai elemen masyarakat Banten, mulai dari kalangan jawara, pengusaha, politisi, birokrat, 
para kyai, pimpinan Ormas dan aktifis LSM, bahkan juga dari kalangan intelektual kritis di kampus-kampus, meski tidak semassif dari elemen masyarakat lainnya. Berdasarkan riset yang penulis lakukan, mengarus derasnya dukungan dan nyaris bersifat permanen pada setiap perhelatan pemilu maupun pemilukada itu dimungkinkan oleh karena keberhasilan Atut dan keluarga/kerabatnya "merawat" loyalitas dan/atau kepatuhan mereka, melalui beberapa strategi politik selain menempatkan keluarga/kerabatanya dalam jabatan-jabatan eksekutif dan legislatif sebagaimana telah diuraikan di depan (Tabel 1).

Berikut ini adalah beberapa strategi politik yang dilakukan Atut untuk merawat dukungan publik dan loyalitas jejaringnya dalam mempertahankan dan memperluas kekuasaan dinastiknya:

(1) Kontrol terhadap birokrasi melalui proses dan mutasi para pejabat di lingkungan Pemprov Banten. Selama era kepemimpinan Gubernur Ratu Atut proses rekruitmen di lingkungan birokrasi praktis lebih didasarkan pada performa kedekatan dan loyalitas pejabat yang bersangkutan daripada prinsip meritokrasi dan profesionalitas. Salah satu tolok ukur kedekatan dan loyalitas itu dipetakan pada saat perhelatan pemilu atau pilkada. Pejabat yang loyal dan turut membantu proses pemenangan kontestasi akan mendapat prioritas ketika kebijakan mutasi atau rotasi jabatan birokrasi dilakukan. Tolok ukur lain adalah kepatuhan yang nyaris mutlak seorang pejabat kepada Ratu Atut; bahkan sampai batas tertentu kepatuhan kepada anggota keluarga dinasti (wawancara Ali Nurdin, dosen Universitas Mathlaul Anwar Pandeglang, tanggal 28 Januari 2017).

Menurut Boyke Pribadi, dosen Untirta, hampir seluruh pejabat eselon 2,3, dan 4 terutama yang penunjukkannya membutuhkan ijin dari gubernur dan memiliki peran strategis, maka ketika hendak dilantik diminta semacam "ikrar" untuk tunduk dan patuh terhadap kebijakan gubernur dan keluarga besarnya (Wawancara tanggal 1 November 2016). Dengan cara inilah Ratu Atut mengonsolidasikan dan mempertahankan dinasti politiknya melalui kontrol atas jaringan birokrasinya sendiri.

(2) Menguasai asosiasi-asosiasi bisnis (KADIN dan GAPENSI), organisasiorganisasi sosial dan pendidikan (PMI, Tagana, Himpaudi), organisasi olahraga dan kepemudaan (KONI, KNPI, Karang Taruna). Cara ini dilakukan dengan menempatkan anggota keluarga sebagai pimpinan atau pengurus pada ormas dan/atau asosiasi bisnis itu. (Tabel 2 dan 4). Dengan posisi tersebut, anggota keluarga Ratu Atut memiliki peluang dan kesempatan untuk sewaktu-waktu menduduki jabatan strategis lain, terutama dalam mencapai kedudukan sebagai kepala daerah, maupun unsur pimpinan di DPRD (Wawancara Maksuni Husen, Wartawan Kabar Banten tanggal 25 Januari 2017). Dalam praktiknya, penempatan anggota keluarga di ormas dan asosiasi bisnis ini memang menjadi batu loncatan para anggota 
dan kroni Ratu Atut untuk menduduki posisiposisi penting di lembaga legislatif dan eksekutif, atau sebaliknya. Setelah berhasil menduduki jabatan legislatif mereka mengokohkan dirinya pula pada jabatanjabatan di ormas dan asosiasi bisnis.

Secara teknis cara penguasaan ormas dan asosiasi bisnis itu antara lain dilakukan dengan membantu mendanai penyelenggaraan pemilihan kepemimpinan (Musda, Muswil dst) dan "membeli suara" para peserta yang memiliki hak suara untuk mendukung dan memilih calon-calon yang disodorkan keluarga besar Ratu Atut. Demikian yang terjadi dalam hampir setiap musda atau muswil ormas dan asosiasi di Banten (Wawancara Boyke Pribadi). Strategi ini menurut Boyke juga dilakukan dalam kontestasi perebutan kepemimpinan beberapa partai politik di Banten dengan konsekuensi bantuan keuangan (utang jasa) itu kelak harus dibayarkan pada saat keluarga besar memerlukan dukungan politik.

Kelak di bawah kendali anggota keluarga itulah kemudian ormas dan/atau asosiasi bisnis ini secara bersama-sama menjadi mesin politik dalam memobilisasi dukungan publik dan perolehan suara pada setiap kali perhelatan pemilu maupun pilkada dilaksanakan. Dengan demikian kata Boyke, tagline demokrasi di Banten menjadi : "dari keluarga besar, oleh keluarga besar, untuk keluarga besar".

(3) Mengkooptasi elemen-elemen masyarakat sipil lainnya seperti partai politik, ormas, asosiasi pendidikan, LSM, pers, kampus, pesantren, dll) dengan memberikan kucuran dana (hibah APBD maupun dana pribadi) dan bansos untuk kegiatan dan operasional pimpinan/pengurus dan organisasinya, termasuk membiayai perjalanan ibadah haji dan umroh sejumlah ulama dan tokoh masyarakat Banten. Dana hibah dan bansos yang paling spektakuler dikucurkan dalam rentang waktu tahun anggaran 2009 sebesar Rp 74 milyar, tahun 2010 sebesar Rp 290 milyar, dan tahun 2011 sebesar Rp 391 milyar (Irwan, 2016: 78). Dalam laporan Majalah Teras (2011), dana hibah dan bansos ini dikucurkan kepada ratusan organisasi/lembaga di antero Banten. Dana hibah dan bansos ini, selain diduga digunakan untuk biaya pemenangan Pilgub 2011, juga dimaksudkan sebagai modus Ratu Atut untuk memelihara loyalitas dan dukungan politik dari berbagai elemen masyarakat sipil. (Wawancana Uday Suhada tanggal 16 Oktober 2016 dan Ali Nurdin). Merujuk pada tulisan Hamid (2010), modus bercorak kooptatif ini sudah dilakukan Ratu Atut pada saat-saat menjelang perhelatan Pilgub 2006.

Strategi kooptasi lain dilakukan dengan cara bagi-bagi proyek pembangunan yang didanai oleh APBD. Dalam konteks ini para pengusaha yang memperoleh proyek melalui kebijakan Ratu Atut yang dieksekusi oleh Chaeri Wardana (Wawan) diharuskan memberikan bantuan keuangan kepada kronikroni yang membutuhkan untuk kegiatan- 
kegiatan strategis dalam rangka memanfaatkan ormas-ormas yang dipimpin mempertahankan kepentingan keluarga besar. oleh keluarga Ratu Atut. Himpaudi yang Selanjutnya dilakukan pemantauan secara diketuai Ade Rossi (isteri Andika Hazrumy) ketat terhadap pengusaha yang mendapatkan proyek, apakah dari keuntungan proyek tersebut digunakan untuk membantu jaringan keluarga besar dinasti atau tidak. Jika tidak ada kontribusi yang signifikan terhadap kepentingan keluarga besar dinasti, maka secara bertahap jatah proyeknya akan dikurangi. Bahkan tidak menutup kemungkinan akan dilakukan tekanan secara hukum (Wawancara dengan Boyke Pribadi).

(4) Membeli suara para pemilih pada setiap pelaksanaan pemilu maupun pemilukada melalui timses dan jejaring yang dibangunnya di seluruh kabupaten dan kota di Banten. Praktik money politics ini dilakukan dengan beragam cara dan melalui berbagai jaringan yang berhasil dikooptasi bahkan dikendalikan, selain tentu saja melalui tim sukses dan/atau organ yang dibentuk khusus untuk memenangkan para kandidat dari lingkungan keluarga Ratu Atut pada setiap pemilu atau pilkada (Wawancara dengan Uday Suhada, Direktur Allip, 16 Oktober 2016 dan 14 Mei 2017). Melalui jaringan birokrasi biasanya dilakukan dengan memanfaatkan koneksitas fungsional lembaga birokrasinya. Misalnya oknum-oknum birokrat pada Dinas Pertanian digunakan sebagai jalur untuk menyebarkan money politics itu ke para pemilih melalui kelompokkelompok tani. Modus jejaring koneksitas fungsional ini juga dilakukan dengan misalnya, kerap digunakan sebagai jalur penyebaran money politics ke guru-guru pendidikan anak usia dini (TK, TPA, RA).

Strategi membeli suara pemilih ini juga dilakukan melalui jaringan ketokohan baik formal maupun informal hingga ke tingkat akar rumput. Di kalangan tokoh formal, para Kepala Desa berperan penting dalam pendistribusian money politics ini kepada para pemilih. Sementara di kalangan tokoh-tokoh informal, para kyai dan jawara merupakan simpul-simpul penting melalui siapa money politics itu disalurkan kepada pemilih. Besaran money politics sangat beragam; berada di kisaran Rp 20.000,sampai dengan Rp 100.000,- per amplop; dalam beberapa kasus money politics ini juga berbentuk sembako (Wawancara dengan Uday Suhada).

Ada satu organ penting yang menjadi mesin pendulang suara melalui strategi money politics ini, yakni Relawan Banten Bersatu (RBB) yang dibentuk almarhum Chasan Socihb (ayahanda Ratu Atut) pada bulan Mei 2006. Menurut Suhada, RBB ini awalnya dibentuk dengan tujuan khusus untuk mengimbangi suara Tryana Syam'un (pesaing pasangan Atut Chosiyah-Masduki dalam Pilgub 2006) yang berasal dan memiliki basis suara kuat di Banten Selatan, khususnya Pandeglang. Sejak Atut berhasil memenangi Pilgub 2006 RBB kemudian diperluas dan 
diperkuat keberadaannya; dan setiap kali perhelatan pemilu/pilkada menjadi mesin politik yang sangat penting dalam menjalankan strategi money politics ini. Melalui jaringan pengurus dan anggota RBB inilah amplop-amplop berisi uang ditebar ke para pemilih.

Demikian meluas dan kokohnya bangunan dinasti politik Ratu Atut yang ia rintis sejak menduduki jabatan Gubernur Banten definitif tahun 2005 itu, hingga malapetaka politik yang dialaminya tahun 2013 silam nyaris tidak berpengaruh terhadap soliditas dan kekuatan dinasti politiknya. Sebagaimana telah disinggung di depan, pada tanggal 17 Desember 2013 lalu KPK menetapkan Ratu Atut Chosiyah sebagai tersangka kasus suap sengketa Pemilukada Lebak di Mahkamah Konstitusi (MK) bersama-sama dengan adiknya, Tb. Chaeri Wardana (Wawan). Pada waktu itu, banyak orang menduga --atau lebih tepatnya mungkin berharap-- bahwa dinasti politik keluarga Atut akan segera runtuh dan berakhir. Setidaknya akan mengalami keguncangan luar biasa. Gandung Ismanto (2013), akademisi Untirta yang rajin mengkritisi kebijakan Pemprov Banten misalnya, mengungkapkan bahwa penetapan tersangka Ratu Atut merupakan suatu guncangan dahsyat yang dampaknya lebih besar dibandingkan guncangan pertama ketika Wawan ditangkap. Gandung menganalogikannya dengan tsunami politik bagi keluarga besar Atut.
Harapan atau prakiraan itu di kemudian hari ternyata meleset. Hanya berselang sepuluh hari sejak penetapan status tersangka itu, tepatnya tanggal 27 Desember 2013, Tatu Chasanah, adiknya justru berhasil memenangi kontestasi di arena Musdalub DPD Partai Golkar Banten, mengalahkan rivalnya, Tb. Iman Ariyadi, Walikota Cilegon. Fakta ini menjelaskan dengan sangat lugas, bahwa kekuatan dinasti politik Ratu Atut masih solid dan tidak serta merta dapat digoyahkan dengan mudah.

Sekitar dua bulan kemudian, tepatnya 21 Pebruari 2014, Tanto Warsono Arban, menantu Ratu Atut juga dilantik menjadi Ketua DPD KNPI Provinsi Banten, meneruskan kepemimpinan Aden Abdul Kholiq yang tidak lain adalah suami Ratu Lilis Karyawati, adik tiri Ratu Atut. Ini adalah fakta kedua yang menjelaskan bahwa soliditas dinasti politik Ratu Atut masih terjaga dan tidak tergoyahkan. Perlu segera dikemukakan dalam kaitan ini, bahwa sejauh ini KNPI Banten juga merupakan salah satu ormas yang berhasil dikooptasi dan menjadi salah satu pilar kekuatan dinasti politik Ratu Atut.

Kemudian, sebagaimana sudah dipaparkan didepan, Pemilu legislatif 2014 yang dapat menjadi parameter untuk mengukur soliditas dan kekuatan dinasti politik Ratu Atut juga berhasil dilewati dengan sukses. Beberapa anggota keluarga Ratu Atut, terpilih menjadi anggota legislatif baik di pusat maupun di Provinsi Banten. Andika Hazrumy dan Andiara Aprilia Hikmat 
(keduanya anak Ratu Atut), masing-masing terpilih menjadi anggota DPR RI dan DPD RI. Sementara kedua menantunya, Tanto Warsono Arban dan Ade Rossi Khaerunnisa, masing-masing terpilih menjadi anggota DPRD Banten. Kecuali posisi Ketua Kadin Provinsi Banten yang kini dijabat oleh Mulyadi Jayabaya, mantan Bupati Lebak, berbagai jabatan strategis baik di partai politik maupun ormas (kepemudaan, olahraga, sosial dan budaya) di Banten sejauh ini masih banyak yang diduduki oleh anggota keluarga Ratu Atut.

Fakta paling mutakhir yang dapat menjelaskan dengan lugas, betapa masih solid dan kuatnya dinasti politik Ratu Atut adalah keberhasilan tiga orang anggota keluarganya memenangi Pemilukada serantak 9 Desember 2015 lalu. Mereka adalah Tatu Chasanah (adik kandung) yang terpilih sebagai Bupati Serang; Airin Rachmy Diani (adik ipar) yang terpilih menjadi Walikota Tangerang Selatan; dan Tanto Warsono Arban (menantu) yang terpilih menjadi Walik Bupati Pandeglang. Dominasi keluarga Ratu Atut di pentas demokrasi elektoral ini kemudian dilengkapkan dengan keberhasilan Andhika mendampingi Wahidin Halim pada Pilkada serentak gelombang kedua yang berhasil memenangi kontestasi Pilgub. Tanggal $12 \mathrm{Mei}$ lalu, Andhika Hazrumy dilantik sebagai Wakil Gubernur Banten periode 2017-2022.

Selain kemampuan mensinergikan dukungan politik massa, jejaring dan strategi politik yang dimainkannya sebagaimana diuraikan di atas, keberhasilan Ratu Atut mengokohkan, memperluas dan mengembangkan dinasti politiknya juga dimungkinkan oleh ketersediaan modal materi (sumber daya finansial) yang dimilikinya. Dengan topangan kekuatan materi inilah pula, berbagai strategi politik di atas itu dijalankan, terutama strategi penguasaan asosiasi bisnis dan organisasi sosial-kemasyaratan; kooptasi elemen-elemen masyarakat sipil melalui kucuran dana operasional dan kegiatan; serta membeli suara pemilih pada setiap perhelatan pemilu maupun pilkada.

Berikut ini ringkasan dan perkembangan data harta kekayaan Ratu Atut dan beberapa anggota keluarga besarnya yang menduduki jabatan publik (Kepala Daerah, Wakil Kepala Daerah dan Anggota DPR/DPRD) berdasarkan dokumen LHKPN KPK yang dirilis oleh berbagai media pada tahun 2013 saat berlangsung proses penyidikan terhadap Ratu Atut terkait kasus suap Pilkada Lebak tahun 2013 (kompas.com, detik.com, viva.co.id) dan terkonfirmasi di database KPU Provinsi Banten dan KPU Kabupaten dan Kota se-Banten.

Tabel 5. Ringkasan Data dan Perkembangan Harta Kekayaan Dinasti Ratu Atut Chosiyah Berdasarkan Dokumen LHKPN (dalam Milyar Rupiah).

\begin{tabular}{|c|c|c|c|c|c|c|c|}
\hline \multirow[t]{2}{*}{ No } & \multirow[t]{2}{*}{ Nama } & \multicolumn{6}{|c|}{ LHKPNLHKPNLHKPN|LHKPNEHKPN|LHKPN } \\
\hline & & 2006 & 2008 & 2009 & 2010 & 2011 & 2013 \\
\hline 1 & Atut Chosiyah & 41,93 & - & - & - & 37,73 & - \\
\hline 2 & Hikmat Tomet & - & - & 33,85 & - & - & - \\
\hline 3 & Andika Hazrumy & - & - & 19.60 & - & - & - \\
\hline 4 & Tatu Chasanah & - & - & - & 9.08 & - & - \\
\hline 5 & Tb. Khaerul Jaman & - & 000 & - & - & - & 000 \\
\hline 6 & Airin Rachmi D & - & - & - & 103,94 & - & - \\
\hline 7 & Heryani & - & - & - & 26,51 & - & - \\
\hline
\end{tabular}
Sumber: Data diolah dari berbagai sumber. 
Catatan: Dokumen LHKPN dalam tabel ini adalah LHKPN yang digunakan oleh keluarga Ratu Atut untuk memenuhi salah satu kewajiban sebagai calon Kepala Daerah, Wakil Kepala Daerah atau Calon Anggota Legislatif; dan catatan tahun dalam tabel adalah tahun penyelenggaran Pilkada atau Pemilu Legislatif dalam rentang waktu kepemimpinan Ratu Atut sebagai Gubernur Banten. Tahun 2007 tidak ada Pilkada maupun Pileg

Sementara itu, total harta kekayaan Tb. Chaeri Wardhana (Wawan), adik kandung Ratu Atut yang tidak pernah menduduki jabatan publik karena fokus berkiprah di dunia usaha itu, berdasarkan dokumen LHKPN Airin Rachmi Diany (isteri Wawan) pada tahun 2010 sebesar Rp 103.944 milyar. Kekayaan ini antara lain tersebar dalam harta tidak bergerak berupa bangunan rumah yang berdiri di atas tanah hampir 1 hektar di kawasan Kuningan Jakarta dan tanah yang tersebar pada ratusan lokasi (berdasarkan jumlah sertifikat yang dilaporkan Airin ke KPK sebanyak 102 sertifikat dan hasil temuan penyidikan KPK dalam kasus suap Pilkada Lebak sebanyak 200 sertifikat). Sementara harta bergerak dari total kekayaan Wawan tersebar antara lain dalam bentuk puluhan kendaraan: 2 unit Ferrari, 2 unit Toyota Land Cruiser, 1 unit Rolls Royce, 1 unit Lamborghini Aventandir, 1 unit Nissan GTR, 1 unit Bentley, 1 unit Lexus, 1 unit Toyota Camry, dan 1 unit Kijang Inova.

\section{Kesimpulan}

Berdasarkan uraian dari temuan dan diskusi tersebut di atas, dapat disimpulkan, bahwa gejala awal kebangkitan dinasti politik di Banten sudah dimulai sejak daerah ini menjadi provinsi yang mandiri, terpisah dari Jawa Barat pada tahun 2000. Lebih tepatnya sejak proses pemilihan gubernurwakil gubernur periode pertama tahun 20012006 ketika orang kuat Banten, Chasan Sochib berhasil menyandingkan anaknya, Ratu Atut Chosiyah sebagai Wakil Gubernur mendampingi Gubernur Djoko Munandar pada Pilgub 2001 yang penuh intimidasi. Akan tetapi proses konsolidasi dan penguatan bangunan dinastinya baru berlangsung setelah Ratu Atut menggantikan posisi Djoko Munandar sebagai gubernur yang diberhentikan dari jabatannya pada tahun 2005 lantaran kasus korupsi.

Konsolidasi dinasti itu semakin kokoh bahkan kemudian mengalami perluasan, persebaran dan pertumbuhan (proliferasi) demikian rupa setelah Ratu Atut berhasil memenangi perhelatan Pilgub 2006, pilgub pertama di Banten yang diselenggarakan secara langsung. Proliferasi dinasti ini berlangsung bukan saja pada arena kehidupan politik, melainkan juga menyebar di arena kehidupan non-politik masayarakat, seperti di arena bisnis, sosial budaya, kepemudaan, bahkan ormas keagamaan. Selain berhasil menempatkan keluarga/kerabatnya dalam jabatan-jabatan politik baik eksekutif (Kepala Daerah) 
maupun legislatif (Anggota DPR dan DPRD), Ratu Atut juga sukses menyebar dan menempatkan keluarga dan kerabatnya dalam jabatan-jabatan partai politik, asosiasi bisnis, organisasi kemasyarakatan, organisasi sosial, dan organisai kepemudaan di Provinsi Banten.

Keberhasilan Ratu Atut dalam mengkonsolidasikdan dan memperluas jejaring kuasa dinastinya didukung oleh berbagai strategi politik yang dilakukannya terutama sejak ia menjabat guebrnur. Beberapa startegi itu antara lain merawat loyalitas para pendukungnya melalui berbagai bentuk pemberian fasilitas bantuan hibah, proyek dll; melakukan kontrol penuh terhadap birokrasi melalui proses rekruitmen dan mutasi para pejabat di lingkungan Pemprov Banten; menguasai asosiasiasosiasi bisnis, organisasi-organisasi sosial dan pendidikan, organisasi olahraga dan kepemudaan; mengkooptasi elemen-elemen masyarakat sipil lainnya seperti partai politik, ormas, asosiasi pendidikan, LSM, pers, kampus, pesantren, dll dengan memberikan kucuran dana (hibah APBD maupun dana pribadi) untuk kegiatan dan operasional pimpinan/pengurus dan organisasinya, termasuk membiayai perjalanan ibadah haji dan umroh para ulama dan tokoh masyarakat Banten; dan membeli suara para pemilih pada setiap pelaksanaan pemilu maupun pemilukada melalui timses dan jejaring yang dibangunnya di seluruh kabupaten dan kota di Banten.

\section{Saran}

Beberapa saran penting untuk direkomendasikan terkait studi tentang gejala proliferasi dinasti politik di Banten ini adalah sebagai berikut:

Pertama, untuk mengurangi dan/atau menghambat proses perluasan praktik dinasti di daerah suatu ikhtiar komprehensif yang lebih serius, sistematik dan tentu saja legal penting dilakukan, baik melalui perangkat peraturan perundangan maupun melalui proses edukasi politik masyarakat yang diharapkan dapat menumbuhkan kesadaran publik perihal potensi buruk dampak praktik dinasti dalam kehidupan sosial-politik di daerah. Selain itu, kontrol dan perimbangan oleh masyarakat sipil terhadap kekuasaan pemerintahan daerah juga perlu ditingkatkan dengan memperkuat peran-peran dan partisipasi masyarakat sipil dalam kerangka penyelenggaraan pemerintahan daerah.

Kedua, upaya mengurangi dan/atau menghambat proses merebaknya kebangkitan dinasti politik dan gejala proliferasinya di daerah juga perlu dilakukan pada sisi hulu proses pilkada, dengan antara lain memperkuat pelembagaan partai-partai politik di daerah serta meningkatkan integritas para elitnya sedemikian rupa sehingga tidak mudah terjebak dalam pusaran politik transaksional dengan para 
pemilik modal (local strongmen, local bossis) yang selama ini praktis mengendalikan proses kandidasi dan perhelatan pilkada untuk kepentingan keluarga dan kelompok oligarkhnya sendiri.

Ketiga, untuk memetakan lebih tajam dan komprehensif terkait gejala proliferasi dinasti ini, suatu penelitian lebih lanjut penting dilakukan, terutama dalam rangka mendeteksi dan memetakan berbagai dampak negatif dari praktik dinasti dan proliferasinya di berbagai daerah. Dalam kaitan ini, penulis sendiri sedang terus melakukan riset di Banten terkait dampak buruk praktik dinasti terhadap perkembangan demokrasi dan merebaknya praktik-praktik korupsi di daerah.

\section{Daftar Pustaka}

Agustinus, L. (2010). Dinasti Politik pascaotonomi Orde Baru: Pengalaman Banten. Prisma, 29 (3), 102-116.

Agustino, L. (2014). Politik Lokal dan Otonomi Daerah. Bandung: Alfabeta.

Alhumami, Amich, 2016, dalam www.akbarfaizal.com, diakses tanggal 2 Maret 2017.

Asako, Y., Iida, T., Matsubayashi, T., \& Ueda, M. (2015). Dynastic politicians: Theory and evidence from Japan. Japanese Journal of Political Science, 16 (1), 5-32.

Dal Bó, E., Dal Bó, P., \& Snyder, J. (2009). Political dynasties. The Review of Economic Studies, 76 (1), 115-142.

Djafar, M. (2008). Demokratisasi, DPRD, dan Penguatan Politik Lokal. Jurnal Poelitik, 1 (1).

Djati, W. R. (2013). Revivalisme Kekuatan Familisme dalam Demokrasi: Dinasti
Politik di Aras Lokal. Jurnal Sosiologi Masyarakat, 18 (2).

Eisenstadt, S. N., \& Roniger, L. (1984).

Patrons, clients and friends: Interpersonal relations and the structure of trust in society. Cambridge University Press.

Hamid, A. (2015). Observation of Democratic Decentralization in Indonesia during 2009-2014: Political Dynasty in Banten Province and Populism in Jakarta Province (Doctoral dissertation, School of Global Studies Doshisha University Observation of Democratic Decentralization in Indonesia during 2009-2014: Political Dynasty in Banten Province and Populism in Jakarta Province A Dissertation Submitted in Partial Fulfillment of the Requirements of the Doctoral Degree at the Graduate School of Global Studies, Doshisha University).

Hamid, A. H. A. (2013). Memetakan Aktor Politik Lokal Banten Pasca Orde Baru: Studi Kasus Kiai dan Jawara di Banten. POLITIKA: Jurnal Ilmu Politik, 1 (2), 32-45.

Haryanto. (2009). Elit Politik Lokal dalam Perubahan Sistem Politik. JSP Jurnal Ilmu Sosial dan Ilmu Politik, 13 (2).

Irawan, Ade dkk., (2016). Dinasti Banten, Keruntuhan dan Kebangkitannya Kembali. Malang: Intrans Publishing

Ismanto, Gandung, 2013, dalam www.kompas.com, diakses tanggal 14 Maret 2017.

Jurnal Konstelasi, Analisis Berkala Perhimpunan Pendidikan Demokrasi (P2D), Nomor 21 April 2011.Kenawes, Y. C. (2015). The rise of political dynasties in a democratic society. Dalam www. isrsf. org.

Majalah Gatra, No.52 Tahun XIX, 31 Oktober-6 November 2013. 
Majalah Hukum TIRO, Edisi 62/September 2011.

Marijan, K. (2010). Sistem politik Indonesia: konsolidasi demokrasi pasca-Orde Baru. Kencana Prenada Media Group.

Masaaki, O., \& Hamid, A. (2008). Jawara in Power, 1999-2007. Indonesia, (86), 109-138.

van Klinken, G. A., \& Nordholt, H. S. (2008). Politik lokal di Indonesia.

Querubin, P. (2010). Family and politics: Dynastic persistence in the Philippines. Unpublished manuscript, MIT.

Sidel, J. T. (1999). Capital, coercion, and crime: Bossism in the Philippines. Stanford University Press.

Sugiyono. (2008) Metode Penelitian Kuantitatif, Kualitatif dan R\&D, Bandung: Alfabeta.

Thompson, M. R. (2012). Asia's Hybrid Dynasties. Asian Affairs, 43(2), 204220.

Zuhro, Siti, 2017, dalam www.beritasatu.com, diakses tanggal 12 Januari 2017. 